\title{
Tutorial Teaching: A New Paradigm for the Development of Competencies
}

\author{
Marco Ferreira
}

Instituto Superior de Educação e Ciências, Lisboa

doi: 10.7358/ecps-2013-008-ferr

marcomaiaferreira@gmail.com

\section{LINSEGNAMENTO TUTORIALE: UN NUOVO PARADIGMA PER LO SVILUPPO DELLE COMPETENZE}

\begin{abstract}
Higher education institutions have been confronted with demanding challenges regarding especially the quality of teaching and learning. The constant technological evolution, the rapid growth in the production and dissemination of scientific knowledge, and the constructivist views of learning bring into question the precariousness of rigid answers, and the kind of information conveyed by textbooks or crystallized lectureship. In addition, academic staff have been the target of an ongoing, widespread and sometimes superficial process of innovation, and the object of evaluation and criticism by the public and by a society that has changed profoundly in the last half century. This article discusses the challenges and the transformations in teaching and learning processes stimulated by the "Bologna Process". Pedagogical processes are intended to go beyond a mere feedback on the accuracy of a given assessment and should become exploratory, constructive and critical, an essential component in the development of a shared teaching and learning process. Reflecting on these issues is fundamental so that professors can gain new competences and implement new teaching and learning practices in their daily routines.
\end{abstract}

Keywords: Bologna Process, Higher education, Learning, Teaching, Tutorial teaching. 


\section{INTRODUCTION}

Nowadays, learning has to be conceived as a cognitive, constructive, meaningful, mediated and self-regulated process rather than as an impersonal process of memorization and acquisition of factual knowledge. Teaching must reach beyond traditional lecturing and assessment of written assignments to become a question-raising activity and an awareness-raising enterprise involving the organization and the monitoring of learning. In the same token, professors must act beyond their role as knowledge transmitters and evaluators to become facilitators, monitors and, to some extent, role models to students in order to help them develop as critical, creative subjects, able to build their intellectual autonomy (Santos, 2004). The quality of the educational process implies the reorganization of curricula and a change in teaching methodologies (Simão, Santos, \& Costa, 2002). Beyond that, it is related to the quality of the training and professional competence of the teaching staff, who have to develop a new corpus of skills and expertise in order to adopt new approaches to teaching and to deal competently with factors such as the heterogeneity of the student population, the rapid growth of educational attainment, and the influential role played by the media in modern societies.

Recent literature indicates that the path to success lies in the adoption of new approaches to teaching, the implementation of diverse strategies and different models of access to knowledge in formal and informal learning environments. In this context, tutoring is particularly important if we consider the academic model that is intended for Europe. Tutoring programs play a relevant role in the adoption and reinforcement of the new approaches to teaching and learning. Tutoring activities can be grouped into three main types: pedagogical, social and managerial.

Tutorial activities aim at enabling students to learn in an individual or small group environment, developing their subject knowledge, and developing their effective learning and thinking skills. This involves a number of different activities: modeling appropriate learning behaviors, supporting and developing student subject learning by introducing ideas and insights, questioning and probing students' responses, and focusing the discussions on critical concepts, principles and skills.

Tutors need to engage in, and encourage, «social» activities with their students. This includes creating a friendly, informal environment necessary for successful academic learning, as well as acknowledging students' contributions and promoting collaborative work. Tutors also have a managerial role in setting the agenda and planning the tutoring sessions. This includes a variety of tasks such as introducing the learning group, establishing the 
expected outcomes, introducing and setting tasks, focusing and re-focusing the discussions, setting the pace and managing the time, summarizing the outcomes, closing the discussions or conferences. Tutoring in higher education cannot be narrowly defined as the concept may change from institution to institution, and it can be implemented following a myriad of models. Whatever the case, the main objective of tutoring is to promote and enhance the overall development of the student as a human being. It is thus an important component of graduate and post-graduate programs as it provides students with the opportunity to seek help on a one-to-one basis or in a small group setting. In this way the tutor not only helps with academic work, but also becomes a mentor, a friend and a role model.

\section{WHAT PROFESSORS AND STUDENTS CAN DO TO ENRICH TEACHING AND LEARNING PROCESSES}

Currently, many professors have concepts of learning that lead to less effective and less flexible teaching methods. In this case, teaching is seen as a process of knowledge transfer in which the sole purpose is the fulfilment of the program. Professors often see students as lazy, confused and not involved in their tasks, but students' motivation and clarity of thought are in part a reflection of their experiences in class (Entwistle, 1990).

Changing such concepts is not, however, an easy task. The literature in the field of psychology abounds with examples of the difficulties in changing deeply rooted attitudes and concepts. The evidence on conceptual change suggests that the individual has to perceive a reason for the change. If not, the individual continues to feel comfortable and adequate, and change is unlikely to occur. Professors need to promote a wide range of experiences, challenging the existing conceptions and misconceptions of teaching. These experiences should be carefully organized and presented in a climate of acceptance and support among professors. The experiences of teaching and learning must be outlined in order to fit prior knowledge and the learning skills of the students. Apparently, there seems to be the orthodox idea that learning of these new models of teaching should take place in workshops, where participants (professors) negotiate the contents and the learning activities. This principle contradicts the most recent research, which indicates that teachers learn also through readings and by participating in conferences, debates and meetings with colleagues. Professors can make the most of these presentations in order to glean the subjects of personal interest and the useful ideas for their area of teaching (Bedford, 2004). 
The introduction of more innovative and creative teaching strategies in higher education should be enhanced with more positive appraisals during the teachers' evaluation process in order to increase individual efforts that professors make to adapt their teaching to the processes of change. What sometimes happens during the process of evaluation is the opposite: these professors are viewed with suspicion by their own peers (Laurillard, 1993).

It is unlikely that there is only one method of effective teaching to promote deep approaches to study. What is more likely is a solution encouraging professors to use a wide variety of learning experiences facilitating the transmission of knowledge, challenging new ways of thinking, developing processes of cooperation and promoting autonomy in learning (Entwistle, 2000). These teaching approaches result better in institutions that are involved cooperatively in the reassessment of their teaching methods, for example, as part of their procedures for self-evaluation. These processes of change in concepts of teaching emphasize new standards in the evaluation procedures and new institutional policies, giving equal influence to teaching and research. In higher education, it is expected that students learn to think systematically and to use evidence in a particular way for each subject matter. The nature of understanding is the connection between new ideas and the prior knowledge that the student already has, and this new understanding is built in an individual way (Biggs, 1987).

The concept of self-regulated learning has contributed to strengthening the role of the student, making the student an active and independent participant in the learning process. Self-regulated learning is perceived as a regular process of learning behaviour and involves setting goals and monitoring the behaviour to achieve these objectives. This concept of self-regulated learning gives a central role to the use of metacognitive strategies in the students' attributions and their perceptions of competence, involving multiple processes including goal setting, strategic planning, organization and codification of information, metacognition, beliefs, motivation, evaluation and self-reflection process (Zimmerman, 2000).

For effective learning, students have to combine internal and external resources, effective management of time and effort, cognitive and motivational skills and persistence in the task. For Silva (2004), students develop their metacognitive knowledge when they reflect on the demands of the tasks, more specifically when they reflect on the skills and personal strategies to be applied to solve problems and during the review of the work done. The metacognitive knowledge and the use of appropriate learning strategies are essential components when attempting to educate independent and motivated learners and with deep approaches to study. In the development of conceptual understanding, students must build their own frame- 
works of interpretation from the evidence of the arguments and explanations they have heard or read. The level and extent of the construction of these frameworks of interpretation depend in part on the subject matter in question. In the humanities and social sciences, these frameworks can incorporate personal experiences more widely than in the sciences. Nevertheless, in the study of science, students also need to understand concepts through idiosyncrasies (Entwistle, Entwistle, \& Tait, 1992). Laurillard (1993) argued that academic learning must be different from day-to-day learning and this difference involves the distinction between education and perception. The professors' task involves the mediation of learning. The rhetorical activity through which the professor tries to persuade students to change their ways of making sense about the various phenomena, using concepts and ways of thinking characteristic of their subject matter is truly essential.

The approaches to teaching adopted by teachers influence the approaches to study carried out by students and, concurrently, the results of learning (Entwistle, 2000). The teacher's role is, therefore, essential for the development of teaching and learning procedures that allow students to acquire knowledge and to understand and relate new ideas in order to apply and generalize what they learn to everyday situations. Learning will thus be significant, allowing conceptual development and individual understanding - key aspects to a deep approach to study - and a more complex conception of learning.

\section{TUTORING PRACTICES: THEORETICAL FRAMEWORK}

Teaching means privileging the construction/reconstruction of knowledge as a central process of the educational act, involving the encouragement of questioning and the ability of the professor to develop interest in students in identifying sources of information and knowledge. Furthermore, teaching requires motivating students to consult libraries, cultural collections and museums and to appreciate their ability to select and to handle collected information, to work with available technology and to develop a working posture (habitus) in the treatment of methodological issues (Brandão, 1998).

Reflecting on these issues is fundamental so that professors can gain new competences and implement new teaching and learning practices. The Bologna Process has brought new challenges in terms of the pedagogical relationship established between professor and student.

Under this new teaching model, professors are faced with a substantial reduction in the number of hours in the classroom and with an increase in 
the number of hours of professor-student contact and a synergy of learning that should be more effective and dynamic. Pedagogical processes are thus intended to go beyond a mere feedback on the correctness of a given assessment and to become exploratory, constructive and critical, an essential component in the development of a shared teaching and learning process (Ferreira, 2011).

These new learning environments are intended to lead to reflective exercises of conceptualization and a multidisciplinary understanding of phenomena, and thus contribute to the success of this model side by side with the quality of higher education. The current role of the professor in higher education is to create and disseminate knowledge, to enhance interaction with society and to promote proactive innovation in attitudes and behaviors, and the university is intended to be a center for discussion of ideas and an important contributor to human and social progress. Today, the guidance and support needed to give university students the ability to meet current societal challenges has been recognized by higher education institutions, which seek to provide different ways to meet these challenges. Tutoring is a method that these institutions have devised in order to respond to the need for support and guidance that a diverse higher education student body shows (Colvin, 2007).

Due to its scope and its possibilities for intervention, tutoring has many facets, different features and can be implemented in different modes. Boronat, Castaño and Ruiz (2007) allude to several dimensions of tutorial teaching, which are:

a. The legal and administrative tutorial dimension determined under current law.

b. The tutorial teaching and curriculum dimension, which underscores the curriculum, concerning the content and the study programs of curricular units.

c. The tutorial of an academic and training dimension, which represents the help provided to the student so that he or she can successfully develop his or her academic life, promoting autonomy in learning.

d. The personalized tutorial dimension, related to the personal level (the tutor provides special support in case of particular difficulties and advises on the training development of students) and professional future (the professor helps in setting the curricular path and possible career opportunities).

e. The practical tutorial period dimension, which, in certain courses (teaching, medicine, nursing, etc.), has a wide tradition, involving university professors and supervisors of the practices.

f. The distance tutorial dimension, related to e-learning courses. 
g. The tutoring dimension as an attention to diversity, because today, as is characteristic of our diverse society, higher education students have diverse social, economic and cultural profiles.

h. The peer tutoring dimension, found in many international universities, where mentors play an intermediary role and, at the same time, tutors and responsible for one or more students.

The multiple possibilities that the various forms of tutoring have can respond to the need to create, among university teachers and students, a culture of coaching and mentoring. But it is not enough to state this culture as a declaration of intent. The tutoring professor becomes the reference professor for the group of students he or she is responsible for. Martinez (2002) considers that the tutoring professor supervises training as well as human and scientific development, and also monitors the entire learning process of a particular student, which should allow the student to understand his or her strengths and weaknesses. Thus, we can establish a series of targets for tutorial teaching, including: (1) guiding the student toward a better integration in the new university context; (2) informing the student of academic and/or professional issues; (3) encouraging student participation in different areas of university life; (4) reflecting on the student's academic and personal development; (5) highlighting the need for tutoring as an instrument of knowledge and reflection on the process of attaining higher education.

The emphasis given to each of these dimensions lead us to different models of tutoring. Carrasco and Lapena (2005) claim that it is possible to find - at the core of different conceptions of university tutoring - a set of common characteristics, which can be summarized as follows: (a) tutoring is a guidance action to promote and facilitate the global development of students in their intellectual, emotional, personal and social dimensions; (b) tutoring is a teaching task which personalizes university education through individualized monitoring, which facilitates the building of knowledge and the maturation of attitudes of students, helping them in planning and developing their academic experience; (c) tutoring is an action allowing the integration and active preparation of the student at the university, channeling and fostering relations with the different services (administrative, educational, organizational, etc.), and ensuring the proper beneficial use made of different resources provided by the institution.

Combining the new challenges faced by higher education and the new paradigm underlying teaching and learning processes, students and professors have to change academic behaviors in order to meet the actual requirements of training, teaching and learning imposed by $21^{\text {st }}$ century society (Ferreira, 2011). 
Modern pedagogical practices adopt diverse teaching models to promote different levels of understanding in student performance in higher education. These models are based on student-focused teaching and learning methodologies, individualizing learning experiences. The transmission of knowledge is supposed to be diverse; with formal learning activities appealing to students with seminars and group work, and with research projects and field research. This paradigm promotes adequate time for individual and group work, research and critical use of information from the perspective of problem-solving; tutoring and coaching; diverse and flexible curriculum, incentives and rewards, etc. Higher education has an obligation to educate and train people in order to prepare them for working life in society, to exercise their citizenship, and to train them as future and privileged agents of social progress. Thus, the distinctive characteristics of higher education are the development of understanding and the ability to apply knowledge to diverse practical situations. The student is no longer a passive individual, but is now an active and enterprising subject in charge of his or her own learning. This «new student» is, nowadays, perhaps the biggest challenge facing all higher education institutions.

\subsection{Tutoring: determinant factors}

The required changes in teaching and learning processes have been one of the main consequences of the implementation of the Bologna Process. Methodologies now emphasize teamwork, the resolution of interdisciplinary problems, and the integration of theory/practice in the development of skills. The emphasis is focused on the active role of student learning, with the development of technical skills, but also soft skills, revealing tutoring as a proper methodology that contributes to the active involvement of students in the learning processes. The tasks associated with tutoring can be structured as follows:

- showing concern for students' individual learning;

- increasing individual or group motivation, promoting dialogue and moments of conviviality;

- providing support (emotional, career counselling, etc.) to the individual or group;

- encouraging the individual student or group to be ambitious.

Professors who are tutors draw attention to issues related mainly to the attitude that tutors should have towards the individual student or group, emphasizing listening, showing interest and concern, getting close to students, being friendly, honest and open, and trying not to disappoint stu- 
dents (Terrion \& Leonard, 2007).Other skills related to a tutoring process include the constant concern of the tutor in facilitating student learning and in guiding the way in academic tasks in which the students are constantly involved. The role of the tutor is not to direct but to guide, providing all necessary support and encouragement to the student/group, but this requires a rigorous and serious work plan. Being ambitious and communicating and having expectations that go beyond only the acceptable minimum is a position that tutors should show in their relationship with students in order to convey the message that they need to develop quality work. Thus, personal effort is associated with academic achievement and this is a clear message to students. Some tutors compare tutoring work with guidance because there is no standard behaviour or ideal form of intervention. It requires constant readjustments to the time and to the project of each student. In some cases, a more directive approach is better while in others it may be best to raise questions that enable students to quickly find action strategies and to pursue objectives (Terrion \& Leonard, 2007). The tutors must develop their performance by getting training in various areas, particularly in counselling, career management, communication skills, teamwork, conflict mediation, learning styles, etc., in order to provide a set of knowledge and skills that enable them to adapt their behaviour to students' profiles and to the type of situations they encounter in the tutoring process. The tutor's role is mainly related to the characteristics associated with the figure of a "facilitator» and "motivator» and not so much with that of a "technical specialist» and "evaluator». The matter, which emerges from the students regarding the tutor's role, concerns not only the skills that will be developed during the monitoring of the academic tasks, but rather the attitudes that tutors should have in their relationship with students (Guedes, Lourenço, Filipe, Almeida, \& Moreira, 2007). In general, students recognize the importance of the presence of the tutor, without which, they say, it would be more difficult to complete their academic training. Another view on tutoring is described by Hislop (2000), who lists the main characteristics of effective tutors. For this author, the tutor has to be motivated, approachable, visible, explicit, pro-active, discrete, collaborative, technical and capable. This leads us to the need for specific tutor training, and we could say "There isn't a tutor who wants to ... but only who has the profile to be». The tutor is likely to face a range of dilemmas and have the permanent necessity to lead, to design and to establish learning objectives, to transmit knowledge, to evaluate and to assess. There is no simple solution to these dilemmas and the tutor needs to continually revisit and reflect on these issues. The tutor continuously explores the conflict in roles between being the constructivist, facilitator of knowledge construction and being the assignment-marker and student supporter (Dennison, 2000). This conflict is 
expressed in the tutors' increased workload as they attempt to resolve these contradictions. Associated with the issue of boundaries is the issue of style and where the tutor can be placed on the continuum of directive/facilitator style. There is no simple answer to the question, although a more directive style is likely to be more useful with new and inexperienced learners while a more facilitative style is more appropriate for more mature learners and those with experience. We totally agree with Cox (2000) who provides some guidelines for tutors on involving students in academic debate: start from the students' experience; use relevant and authentic materials, e.g. real life case studies; generate enthusiasm and curiosity about each other's perspectives; acknowledge and include different points of view; explain why you are saying what you are saying; summarize and then pose a question to move the debate on; bring in outside ideas. Next, we highlight some tutoring programs and practices that are ongoing in institutions of higher education in Europe. These various tutoring practices and programs were developed by taking into account the concrete practices of each institution in accordance with the characteristics of their students and considering the context in which training is developed.

\section{TUTORING: PRACTICES IN HIGHER EDUCATION INSTITUTIONS}

The tutoring programs developed by the institutions of higher education we contacted are varied and show different strategies in the way to implement and organize programs. For the typology, we can divide the tutoring programs into four distinct groups. This distinction is visible in the objectives of tutoring, the type of tutor selected for intervention and the effective time of the tutoring. A large number of institutions have a tutoring model that we can call "program support for new students». The program has the main objectives of integrating new students in the new academic life and encouraging their personal and interpersonal development to promote their welfare. These programs are structured to privilege peer support, emphasizing the benefits of a close relationship, whose behavior modeling may facilitate the promotion of a good adaptation of new members in the first moments of living in the institution. The motto is to help rather than direct, and to challenge and welcome, by taking into account emotions and thoughts, and by exploring and establishing commitments. A large number of institutions also have a regular program of support for students. This program aims to improve students' learning experiences, to enhance students' learning achievements, to enable the students to develop their group working skills and to enhance career opportunities. In the specific case of assistance to 
foreign students, some institutions run specific programs to support Erasmus students. These students are considered newcomers to a new country and to a new institution of higher education, but not as freshmen, assuming that they are already part of the higher education system in their country of origin and have acquired knowledge in the subjects they are studying. Moreover, some of these students stay for only one semester in their college, which means that the support to be given should focus on more immediate needs to promote rapid integration. It starts from the assumption that the needs of foreign students focus primarily on the clarification of the objectives of their own curriculum, peer communication issues, administrative, financial and logistical matters, and misunderstandings of the new leaning and living environment. There are a few institutions which have a tutoring program to support students with special educational needs, mainly sensory problems. This type of tutoring mainly aims to help students get to know the institution, its operation and geographical context by creating a host network to avoid their social isolation and to help them set and achieve academic goals and to gain further insights into their university course, with a view to adapting and individualizing teaching and learning experiences.

In general, the tutoring programs run at various institutions are developed in five stages:

1. identifying and recruiting the tutors;

2. distributing the students to the tutors;

3. training the tutors;

4. implementing the tutoring program;

5. monitoring and evaluating the program.

The evaluation made by the institutions is that the objectives for promoting the rapid adaptation of students to new circumstances have been and are being achieved, particularly with regard to the component of interpersonal and institutional integration. However, there is some tutor dissatisfaction with the way students take to their new challenges. It appears that the component of the group in some cases does not work. There are more frequent and rewarding contacts at an individual rather than group level. The benefits indicated by the institutions refer to indicators of wellbeing, academic achievement and preparation for the professional and career development of the students. We highlight some ideas that point out the reflections and experiences reported by the institutions. Besides acknowledging the importance of tutoring in different contexts and its positive effects for students and teachers, despite some difficulties and constraints, there are also some other particularly noteworthy aspects:

1. the importance and recognition of the need for teacher training;

2. the need to underline tutor functions on the model advocated; 
3. the construction of instruments facilitating regulation, monitoring and the tutoring process;

4. the structuring of tutoring programs and practices within the nature of support provided and taking into account the mains goals to be achieved;

5. the adoption of collaborative work as a strategy to promote tutoring processes and practices in order to meet the challenges related to student diversity.

We believe that the development of effective tutors involves the development of new processes and activities. This may be crucial in order to facilitate changes in values and beliefs with regard to tutoring programs, and can bring about change in the underlying teaching and learning paradigms.

\section{CONCLUDING REMARKS}

In an age dominated by competitiveness, what is more important than access to knowledge, which grows and changes at a rapid pace, is the fundamental need to develop attitudes that promote lifelong learning and allow occupational flexibility and/or professional behavior enrichment. In this context, we focused on the concept of transferable knowledge or generic skills, which highlight and emphasize personal attributes of the cognitive, social and ethical-moral spheres, as structural pillars of training in higher education (Ferreira, 2008).

The contribution expected of universities for promoting education and training throughout life leads to a gradual widening of the conditions of access to university education, to a greater openness of universities to companies, to the improvement of services to students and to the diversification of their academic training, both in terms of contents and teaching methods. This new paradigm of higher education urges reflection and adjustment amongst the institutions in order to affirm and build a European system of higher education, able to compete with other systems that are conceptually more advanced. The strengthening of the excellence of European universities is the main goal of the whole development of higher education, and thus it is essential to create the conditions for such excellence. The factors associated with quality in higher education are diverse and different. For example, we can mention the need for long-term planning and financing, the need for structures and powerful management practices, the need to develop interdisciplinary training and networks and centers of excellence at European level, to aim for excellence in human resources, and to have greater openness of European universities overseas and better local and regional development 
(European Commission, 2003). Currently, the purpose of higher education should be the acquisition of a scientific mentality and methodological accuracy, of analytical and reasoning ability, and the development of a creative imagination. These aspects are more dependent on a wide and solid scientific training than specialized information or technical training, which is quickly outdated. What is treasured today in the job market is not information, but skills and competences, the mastery of the language of information and computing, and the ability and willingness to continue to learn. We believe that future tutoring processes will be part of the curriculum of courses, and institutions of higher education will begin to look at tutoring as a real possibility of a training model and a way to develop competences and knowledge with quality and excellence.

\section{REFERENCES}

Bedford, T. A. (2004). Learning styles: A review of literature. Toowoomba: University of Southern Queensland.

Biggs, J. B. (1987). Student approaches to learning and studying. Melbourne: Australian Council for Educational Research.

Boronat, J., Castaño, N., \& Ruiz, E. (2007). Dimensión convergente de la tutoría en la universidad: tutoria entre iguales (consultado em junho de $2012 \mathrm{em}$ http:// www.eduonline.ua.es/jornadas2007/comunicaciones/2G3.pdf.).

Brandão, M. (1998). Modos de ser professor. Lisboa: Educa Editora.

Carrasco, V., \& Lapeńa, C. (2005). La acción tutorial en la Universidad de Alicante. In Investigar el diseño curricular: redes de docencia en el Espacio Europeo de Educación Superior, Vol. 2 (pp. 329-358). Alicante: Universidade de Alicante.

Colvin, J. W. (2007). Peer tutoring and social dynamics in higher education. Mentoring \& Tutoring: Partnership in Learning, 15(2), 165181.

Cox, S. (2000). How to herd cats in Piccadilly. Times Higher Education Supplement, 14 April, 36-37.

Dennison, S. (2000). A win win peer mentoring and tutoring program: A collaborative model. The Journal of Primary Prevention, 20(3), 161174.

Entwistle, N. J. (1990). Teaching and the quality of learning in higher education. In N. Entwistle (Ed.), Handbook of educational ideas and practices (pp. 669680). London: Routledge.

Entwistle, N. J. (2000). Approaches to studying and levels of understanding: The influences of teaching and assessment. In J. C. Smart (Ed.), Higher education: Handbook of theory and research, Vol. 15 (pp. 156-218). New York: Agathon Press. 
Entwistle, N. J., Entwistle, A. C., \& Tait, H. (1992). Academic understanding and contexts to enhance it: A perspective from research on student learning. In T. Duffy \& D. Jonassen (Eds.), The design of constructivist learning environments. Berlin: Springer Verlag.

European Comission (2003). O papel das universidades na Europa do conhecimento. Bruxelles: Comissão das Comunidades Europeias.

Ferreira, M. (2008). Rendimento académico no ensino superior: das orientaçóes de estudo às atribuiçôes causais. Dissertação de doutoramento não publicada, Faculdade de Psicologia e de Ciências da Educação da Universidade de Coimbra.

Ferreira, M. (2011). Ensino e aprendizagem no ensino superior. Revista Arquipélago Ciências da Educação, Universidade dos Açores, 12, 121-144.

Guedes, M. G., Lourenço, J. M., Filipe, A. I., Almeida, L., \& Moreira, M. A. (2007). Bolonha. Ensino e aprendizagem por projecto. Lisboa: Centro Atlântico.

Hislop, G. (2000). Working professionals as part-time on-line learners. http://www.aln. org/alnweb/journal/Vol4_issue2/le/hislop/LE-hislop.htm.

Laurillard, D. (1993). Rethinking university teaching. London: Routledge.

Martinez, A. J. (2002). La acción tutorial en la función docente universitaria. In V. Álvarez \& Á. Lázaro (Coords.), Calidad de las universidades y orientación universitaria (pp. 249 281). Málaga: Ediciones Aljube.

Santos, R. (2004). O professor e a produção do conhecimento numa sociedade em transformação. Revista Espaço Académico, 35, 28-36.

Silva, A. L. (2004). A auto-regulação na aprendizagem. In A. L. Silva, A. M. Duarte, I. Sá, \& A. V. Simão, Aprendizagem auto-regulada pelo estudante: perspectivas psicológicas e educacionais (pp. 17-39). Porto: Porto Editora.

Simáo, J. V., Santos, S. M., \& Costa, A. (2002). Ensino superior: uma visão para a próxima década. Lisboa: Gradiva.

Terrion, J. L., \& Leonard, D. (2007). A taxonomy of the characteristics of student peer mentors in higher education: Findings from a literature review. Mentoring \& Tutoring: Partnership in Learning, 15(2), 149-164.

Zimmerman, B. J. (2000). Attaining self-regulation: A social cognitive perspective. In M. Boekaerts, P. Pintrich, \& M. Zeidner (Eds.), Handbook of self-regulation (pp. 13-29). New York: Academic Press.

\section{Riassunto}

Le istituzioni di istruzione superiore si confrontano costantemente per il miglioramento della qualità dell'insegnamento e dell'apprendimento. Lo sviluppo continuo delle tecnologie, la rapida crescita nella produzione e diffusione della conoscenza scientifica e una visione costruttivista dell'apprendimento mettono in discussione la precarietà di risposte rigide 
e il tipo di informazioni veicolate dai libri di testo o da lezioni standardizzate. Inoltre, il personale accademico è stato impegnato in un continuo e diffuso processo di innovazione, spesso poco efficace, e oggetto di valutazione e critiche da parte dell'opinione pubblica e di una società che è cambiata profondamente negli ultimi anni. Questo articolo discute le sfide e le trasformazioni dei processi di insegnamento e apprendimento, provocati dal "Processo di Bologna». I processi pedagogici servono ad andare oltre la semplice valutazione di idoneità e dovrebbero essere esplorativi, costruttivi e critici, una componente essenziale per lo sviluppo di processi condivisi di insegnamento e apprendimento. La riflessione su queste problematiche è centrale per favorire l'acquisizione e formazione da parte dei professori di nuove competenze da attivare nelle loro quotidiane prassi didattiche.

Parole chiave: Apprendimento, Insegnamento, Insegnamento tutoriale, Istituzioni di istruzione superiore, Processo Bologna. 